\title{
Fetal androgens and sexual mimicry in spotted hyaenas (Crocuta crocuta)
}

\author{
M. Lindeque and J. D. Skinner \\ Mammal Research Institute, University of Pretoria, Pretoria 0002, South Africa
}

\begin{abstract}
Summary. Sexual differentiation of the Müllerian duct system and gonad in female fetuses conformed to the general mammalian pattern, whereas the external genital anlage in male and female fetuses developed into the male facies. Interstitial cells occurred in the primary germinal cords of both male and female fetal gonads and are suggested to be the source of androgen production in spotted hyaena fetuses. Maternal transfer of androgens to the fetus via the placenta was negligible. Male fetuses had higher gonadal and plasma concentrations of testosterone than female fetuses, and vice versa for androstenedione. Plasma testosterone was nearly as high in a female 31-day-old fetus as in the twin male, and masculinization of the genital tubercle probably results from an episode of androgen secretion by the fetal gonad although the Wolffian ducts in the female do not respond.
\end{abstract}

\section{Introduction}

Spotted hyaenas are renowned for the fact that the external genitalia of the female closely resemble those of the male. The female spotted hyaena does not represent a case of clitoromegaly or hypospadias, but is completely masculinized, having a peniform clitoris containing the urogenital orifice and fused labiae forming a quadripartite scrotum (Matthews, 1939; Racey \& Skinner, 1979). Matthews (1939) found that masculinization takes place during fetal development, and suggested that androgens secreted by the ovary caused masculinization of the external genitalia. He regarded the abundance of stromal tissue in the adult ovary as indicative of androgen production, thereby implying androgen transfer via the placenta to the fetus.

Racey \& Skinner (1979), after finding relatively low levels of androgens in the adult ovary and adrenal, discarded Matthews' (1939) hypothesis and suggested that the fetal ovary and/or adrenal was the source of the high levels of androgens in the female fetus. The purpose of the present report is to examine the hypotheses of Matthews (1939) and Racey \& Skinner (1979).

\section{Materials and Methods}

\section{Animals}

Fetuses were collected during culling operations in the Kruger National Park from 39 adult females culled, 4 of which were pregnant. Four sets of twin fetuses were available aged 31, 65, 75 and 80 days. Fetal age was estimated following Huggett \& Widdas (1951), using a gestation period of 110 days (Schneider, 1926) and fetal growth velocity of 0.13 (Frazer \& Huggett, 1974). Fetal gonads and adrenals were preserved in $10 \%$ formalin or in a mixture of ethanol 
(96\%), formalin (40\%), glacial acetic acid and distilled water, in the ratio of $3: 1: 1: 5$ (by vol.), and sectioned after routine dehydration and paraffin wax embedding. Sections $(7 \mu \mathrm{m})$ were stained with haematoxylin and eosin.

Blood collected from fetuses (cardiopuncture) and pregnant females (jugular vein) was centrifuged and the plasma was stored frozen until assayed. Fetal gonads, adrenals and placental tissue of some fetuses were removed and stored separately in storage ampoules on solid $\mathrm{CO}_{2}$ or in liquid nitrogen. Occasional samples of blood from the umbilical vein and artery were taken.

\section{Hormone assays}

Testosterone. Estimations were performed on ether extracts of plasma using a highly specific antiserum raised against testosterone-3 carboxymethyl-oxime-bovine serum albumin (Millar \& Kewley, 1976). Cross-reaction with all major naturally occurring steroids was $<0.1 \%$ except for dihydrotestosterone for which it was $5.1 \%$. The intra- and interassay coefficients of variation were $3 \cdot 1$ and $8.4 \%$ respectively. Sensitivity was $5 \mathrm{nmol} / \mathrm{l}$.

Androstenedione. Estimations were performed on hexane-ether $(4: 1 \mathrm{v} / \mathrm{v})$ extracts of plasma using an antiserum raised against androstenedione- $7 \alpha$-hemisuccinate-bovine serum albumin (Miles Yeda, Kiryat Weizman, Rehovot, Israel). Cross-reaction with all major naturally occurring steroids was $<0.5 \%$. The intra- and interassay coefficients of variation were 3.3 and $6.9 \%$ respectively. Sensitivity was $2 \mathrm{nmol} / \mathrm{l}$.

\section{Tissue extractions}

Fetal gonads, adrenals and placental tissue were weighed and homogenized in phosphatebuffered saline (PBS) and extracted twice with diethyl ether and hexane-ether $(4: 1 \mathrm{v} / \mathrm{v})$ for testosterone and androstenedione assays respectively. After evaporation in a nitrogenous atmosphere at $40^{\circ} \mathrm{C}$, precipitates were reconstituted in PBS and included in conventional assays for testosterone and androstenedione. Sensitivities were $0.01 \mathrm{ng} / \mathrm{mg}$ tissue.

\section{Sexual differentiation}

\section{Results}

Enlargement of the genital tubercle to form the penis or peniform clitoris was evident in the youngest fetuses examined ( 31 days). At this stage, however, the reproductive tract was still in the indifferent stage and the two fetuses were sexed on the basis of size dimorphism in the phallus, where the larger phallus was thought to be a male character, as was evident from older fetuses, and as suggested for adults (Neaves, Griffin \& Wilson, 1980). At 50 days of gestation, fetuses could be sexed by the absence of the Müllerian duct system in male fetuses and the presence of well-developed Müllerian ducts in the female fetus. Wolffian ducts in the female fetus of this age were in the first stages of degeneration. The phallus of the male fetus at 50 days of gestation was better developed than that of the female, the latter lacking the long fraenum preputium and prepuce covering the glans of the phallus of the penis.

\section{PLATE 1}

A, adrenal: K, kidney; O, ovary, U, uterine horn: G, glans clitoridus: P. prepuce: F, fraenum preputium; T, testis; $\mathrm{S}$, Scrotal pouch (false in $\$$ ).

Fig. 1. Phenotypic differentiation of the reproduction tract of a female spotted hyaena fetus at 80 days of gestation.

Fig. 2. Phenotypic differentiation of the reproductive tract of a male spotted hyaena fetus at 90 days of gestation. 
PLATE 1

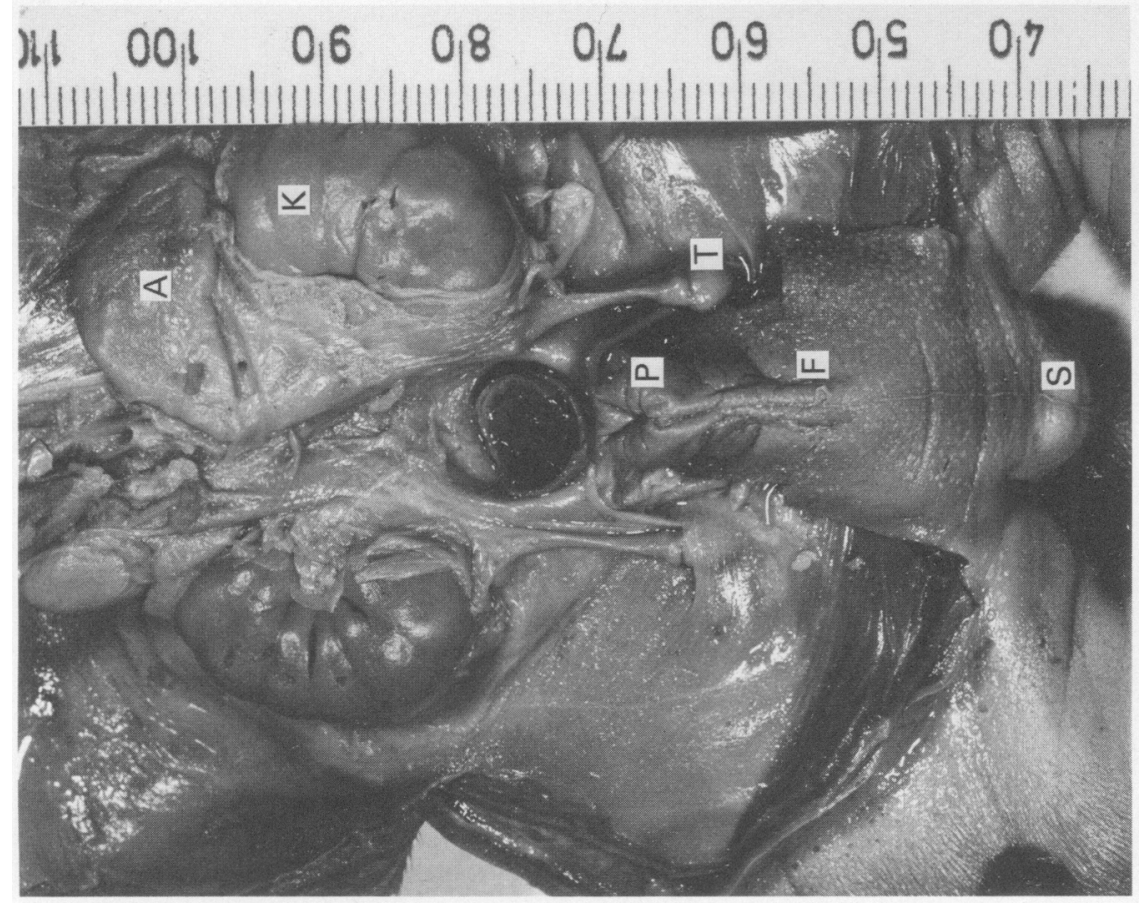

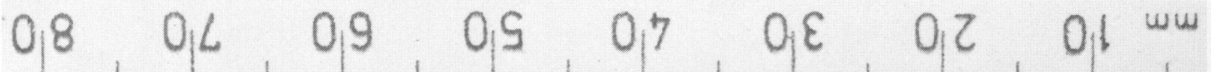

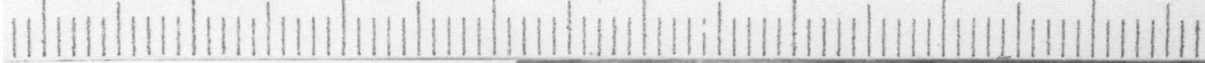

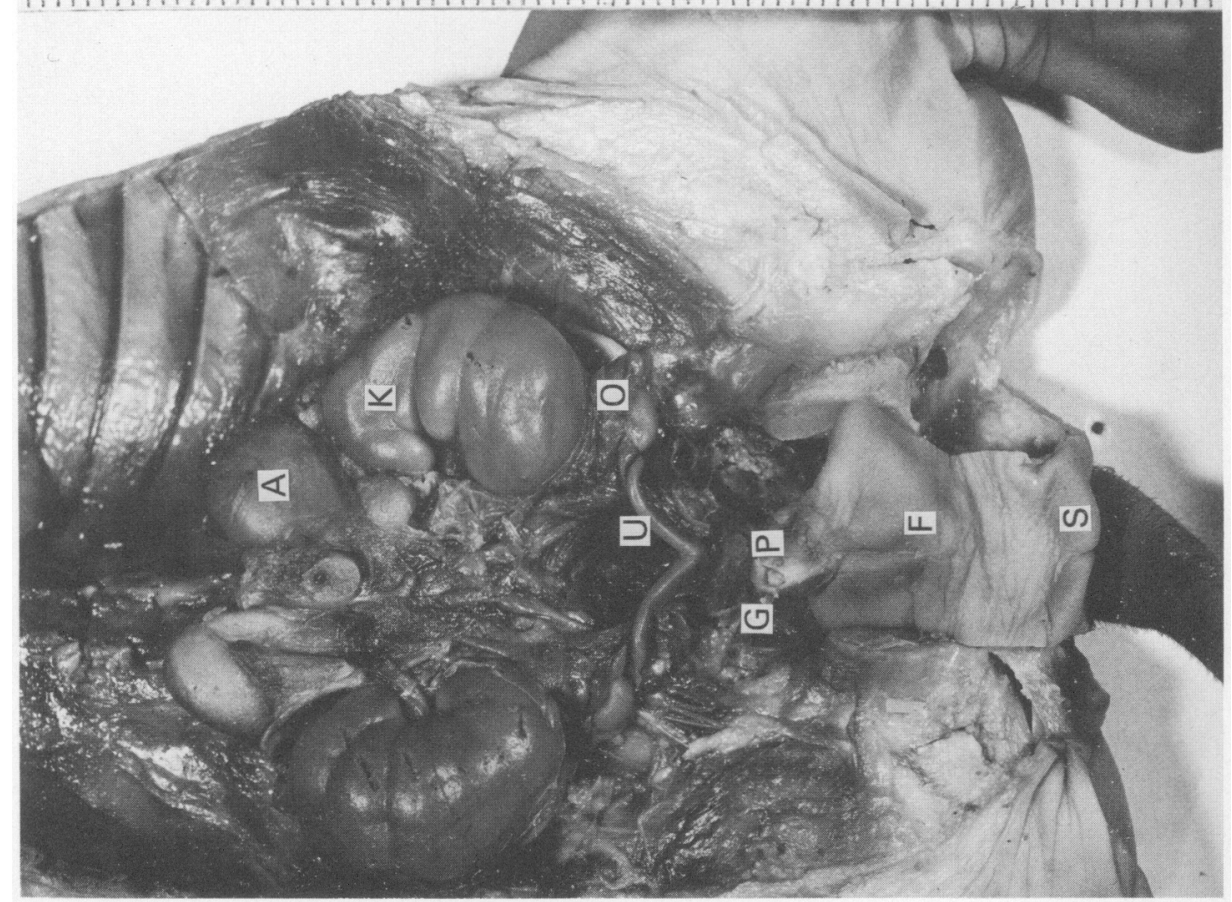


PLATE 2
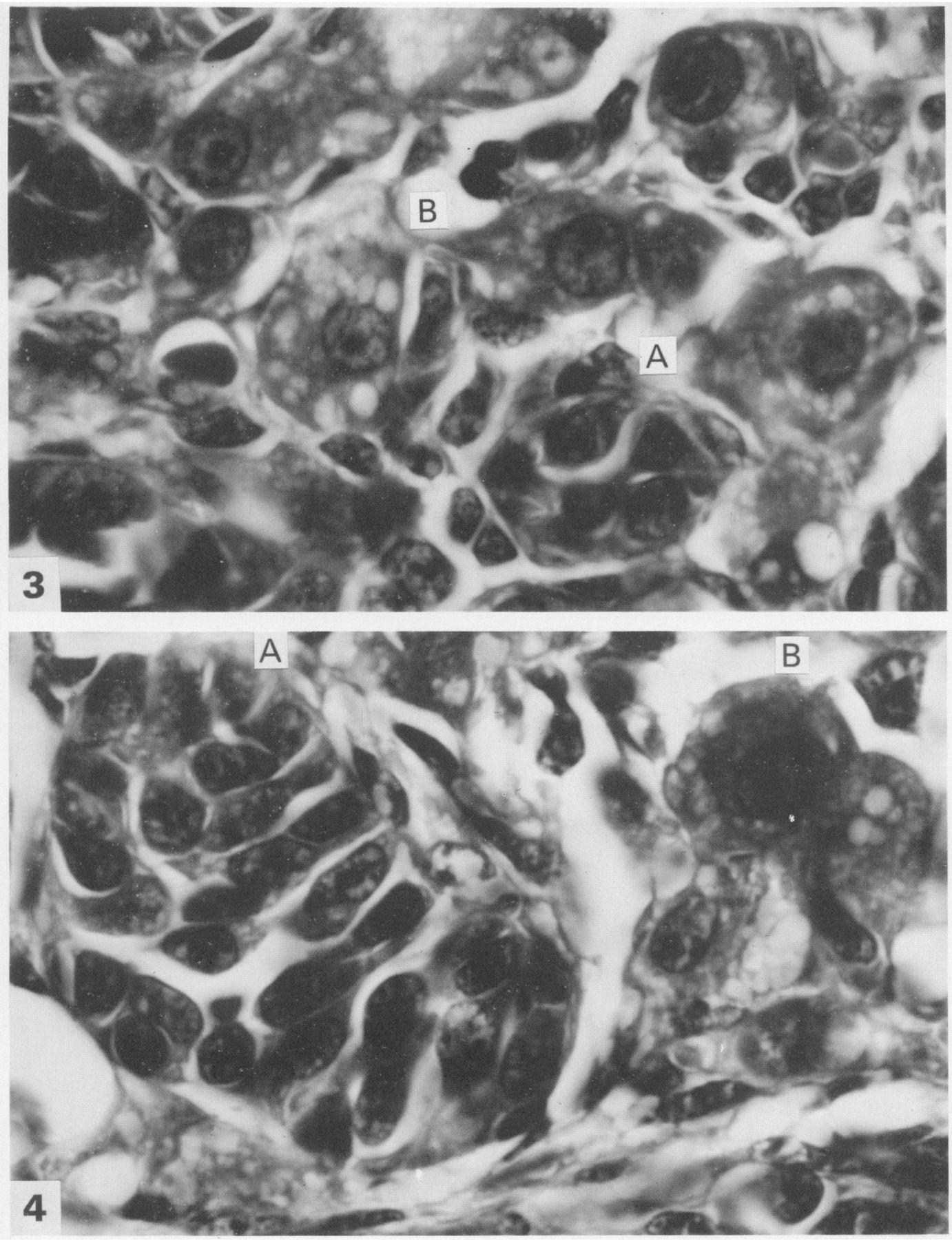
The Müllerian duct system in female fetuses developed according to the usual mammalian pattern. The reproductive tracts of a female ( 80 days) and male ( 90 days) fetus are illustrated in P1. 1, Figs 1 and 2. At 80 days of gestation the Müllerian ducts in the male fetus and the Wolffian ducts in the female fetus had disappeared.

Ovarian differentiation of spotted hyaena fetuses conformed to the general mammalian pattern, except for the presence of numerous large, vacuolated cells in the primary germinal cords of the ovarian medulla (PI. 2, Fig. 3). These cells resembled the interstitial cells associated with the primary and secondary germinal cords of the fetal testis (Pl. 2, Fig. 4) and appear to share a common origin, namely mesodermal (mesenchyme from the gonadal blastema). The medullary region of the fetal ovary shrank in size and became invaded by mesovarian components as gestation progressed, but 'interstitial' cells were still present, although in reduced numbers, in the oldest female fetus examined ( 84 days).

\section{Gonadal, adrenal and plasma androgens in the fetus}

The fetal testis had higher concentrations of testosterone and lower concentrations of androstenedione than did the fetal ovary, but such differences were less distinct at 80 days than at 65 days of gestation (Tables 1 and 2). Adrenal concentrations of testosterone and androstenedione were consistently lower than in the gonads, but total content reflected the same differences found between male and female gonads (Table 1).

Table 1. Gonadal and adrenal concentrations of testosterone and androstenedione in four spotted hyaena fetuses

\begin{tabular}{|c|c|c|c|c|c|c|c|c|}
\hline \multirow{3}{*}{$\begin{array}{c}\text { Fetal } \\
\text { age } \\
\text { (days) } \\
\text { and sex }\end{array}$} & \multicolumn{4}{|c|}{ Testosterone } & \multicolumn{4}{|c|}{ Androstenedione } \\
\hline & \multicolumn{2}{|c|}{ Gonadal } & \multicolumn{2}{|c|}{ Adrenal } & \multicolumn{2}{|c|}{ Gonadal } & \multicolumn{2}{|c|}{ Adrenal } \\
\hline & $\begin{array}{c}\mathrm{ng} / 2 \\
\text { gonads }\end{array}$ & $\begin{array}{l}\mathrm{ng} / \mathrm{mg} \\
\text { tissue }\end{array}$ & $\begin{array}{c}\mathrm{ng} / 2 \\
\text { adrenals }\end{array}$ & $\begin{array}{l}\mathrm{ng} / \mathrm{mg} \\
\text { tissue }\end{array}$ & $\begin{array}{c}\mathrm{ng} / 2 \\
\text { gonads }\end{array}$ & $\begin{array}{c}\mathrm{ng} / \mathrm{mg} \\
\text { tissue }\end{array}$ & $\begin{array}{c}\mathrm{ng} / 2 \\
\text { adrenals }\end{array}$ & $\begin{array}{c}\mathrm{ng} / \mathrm{mg} \\
\text { tissue }\end{array}$ \\
\hline $\begin{array}{r}65 \delta \\
q\end{array}$ & $\begin{array}{r}38.2 \\
2.0\end{array}$ & $\begin{array}{l}1 \cdot 16 \\
0.19\end{array}$ & $\begin{array}{l}5 \cdot 8 \\
3 \cdot 4\end{array}$ & $\begin{array}{l}0.03 \\
0.01\end{array}$ & $\begin{array}{r}2.6 \\
15 \cdot 0\end{array}$ & $\begin{array}{l}0.08 \\
0.20\end{array}$ & $\begin{array}{r}4 \cdot 4 \\
11 \cdot 2\end{array}$ & $\begin{array}{l}0.02 \\
0.01\end{array}$ \\
\hline 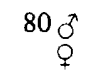 & $\begin{array}{l}62 \cdot 2 \\
47 \cdot 4\end{array}$ & $\begin{array}{l}0.91 \\
0.61\end{array}$ & $\begin{array}{r}11 \cdot 6 \\
7.6\end{array}$ & $\begin{array}{l}0.01 \\
0.01\end{array}$ & $\begin{array}{l}2 \cdot 6 \\
2 \cdot 7\end{array}$ & $\begin{array}{l}0.04 \\
0.03\end{array}$ & $\begin{array}{l}7 \cdot 4 \\
4 \cdot 2\end{array}$ & $\begin{array}{l}0.01 \\
0.01\end{array}$ \\
\hline
\end{tabular}

Plasma concentrations of testosterone and androstenedione followed the same trend as gonadal concentrations (Table 2) and were apparently not related to maternal plasma concentrations of testosterone and androstenedione. The two smallest fetuses ( 31 days) yielded only enough plasma for a testosterone assay, and steroids extracted from tissue removed from the mesonephric region of each fetus were below the minimum limit of assay sensitivity and could therefore not be determined. Plasma testosterone was similar in both fetuses which could be the reason for the external masculinization during the critical stage in differentiation.

Testosterone and androstenedione concentrations in blood from the umbilical vein (placental effluent) were less than in the maternal and fetal circulation at 80 days of gestation (Table 3 ). Plasma from the fetal circulation and maternal circulation greatly differed with regard to the

\section{PLATE 2}

Fig. 3. The medullary region of the fetal ovary at 50 days of gestation containing primary germinal cords (A) and interstitial cells (B) $\times 400$.

Fig. 4. Primary germinal cords (A) and Leydig cells (B) in the fetal testis at 50 days of gestation. $\times 400$. 
Table 2. Plasma concentrations of testosterone and androstenedione in spotted hyaena fetuses and pregnant females

\begin{tabular}{|c|c|c|c|c|c|c|c|c|}
\hline \multirow{2}{*}{$\begin{array}{c}\text { Fetal } \\
\text { age } \\
\text { (days) }\end{array}$} & \multicolumn{4}{|c|}{ Testosterone $(\mathrm{nmol} / \mathrm{l})$} & \multicolumn{4}{|c|}{ Androstenedione $(\mathrm{nmol} / \mathrm{l})$} \\
\hline & $\begin{array}{c}\text { Pregnant } \\
\stackrel{q}{ }\end{array}$ & $\begin{array}{l}\text { Male } \\
\text { fetus }\end{array}$ & Female fetus & $\Delta\left(\sigma^{2}-\emptyset\right)$ & $\begin{array}{c}\text { Pregnant } \\
\stackrel{+}{q}\end{array}$ & $\begin{array}{l}\text { Male } \\
\text { fetus }\end{array}$ & $\begin{array}{l}\text { Female } \\
\text { fetus }\end{array}$ & $\Delta\left(\sigma^{\lambda}-q\right)$ \\
\hline 31 & 3.4 & 25.4 & $22 \cdot 5$ & $2 \cdot 9$ & & & & \\
\hline 65 & 0.1 & $7 \cdot 4$ & $4 \cdot 2$ & $3 \cdot 2$ & 9.2 & $2 \cdot 0$ & $2 \cdot 2$ & -0.2 \\
\hline 75 & $2 \cdot 2(6 \cdot 6)^{*}$ & $12 \cdot 7$ & $-(3 \cdot 1,3 \cdot 5)^{*}$ & $9 \cdot 2$ & $91 \cdot 6$ & $3 \cdot 8$ & - & - \\
\hline 80 & $12 \cdot 6$ & $12 \cdot 4$ & $6 \cdot 9$ & $5 \cdot 5$ & $16 \cdot 0$ & $2 \cdot 5$ & $2 \cdot 5$ & $0 \cdot 0$ \\
\hline
\end{tabular}

* From Racey \& Skinner (1979).

Table 3. Plasma concentrations (nmol/l) of testosterone and androstenedione in maternal blood, blood from the umbilical artery and vein and the fetal heart, of two hyaena fetuses aged 80 days.

\begin{tabular}{|c|c|c|c|c|c|}
\hline Fetus & Hormone & $\begin{array}{c}\text { Maternal } \\
\text { plasma }\end{array}$ & $\begin{array}{l}\text { Umbilical } \\
\text { vein }\end{array}$ & $\begin{array}{l}\text { Umbilical } \\
\text { artery }\end{array}$ & $\begin{array}{l}\text { Fetal } \\
\text { heart }\end{array}$ \\
\hline \multirow[t]{3}{*}{$\sigma$} & Testosterone & $12 \cdot 6$ & 0.2 & $10 \cdot 9$ & 12.4 \\
\hline & Androstenedione & $16 \cdot 0$ & 1.2 & - & $1 \cdot 2$ \\
\hline & Ratio & 0.79 & 0.17 & - & 4.96 \\
\hline \multirow[t]{3}{*}{ 우 } & Testosterone & $12 \cdot 6$ & 0.5 & $4 \cdot 5$ & 6.9 \\
\hline & Androstenedione & $16 \cdot 0$ & $2 \cdot 7$ & - & $2 \cdot 5$ \\
\hline & Ratio & 0.79 & 0.19 & - & 2.76 \\
\hline
\end{tabular}

ratio of testosterone : androstenedione, which is regarded as the result of endogenous production of testosterone in the male and female spotted hyaena fetuses. Placental concentrations of testosterone were $4 \mathrm{pg} / \mathrm{mg}$ tissue at $31,65,75$ and 80 days of gestation and can therefore not be regarded as a major contributing factor to fetal levels.

\section{Discussion}

The role of androgens in phenotypic differentiation is well understood. Maleness is imposed on the neutral or female state through the action of androgens produced by the fetal testis. The onset of testosterone production precedes the differentiation of the Leydig cells (Lipsett \& Tullner, 1965), but presumably occurs in the mesenchymal Leydig cell primordia (Gondos \& Hobel, 1973) as well as differentiated Leydig cells of the fetal testis (Ellinwood, Brenner, Hess \& Resko, 1980). Androgens maintain the development of the Wolffian duct system, once this has reached the androgen-dependent stage, and induce differentiation of the genital tubercle to form the typical male internal and external reproductive tract. The fetal gonad, however, is not affected by androgens (Jost, 1955; Neumann, Elger, Steinbeck \& Gräf, 1975), apart from occasional hypertrophy of the ovarian medulla, as in androgenized female rabbit fetuses (Jost, 1955; Wilson, Griffin \& George, 1980).

Testosterone levels in male fetuses were always higher than in female fetuses. Androgens have been located in extremely low amounts in the plasma of female fetuses of most species examined (Lipsett \& Tullner, 1965; Resko, 1970; Veyssiere, Berger, Jean-Faucher, De Turckheim \& Jean, 1976; Buhl, Pasztor \& Resko, 1979; Ford, Christenson \& Maurer, 1980; Pointis, Latreille \& Cedard, 1980). The fetal ovary is commonly regarded as the primary source 
of androstenedione (Raeside \& Middleton, 1979), as is the fetal adrenal for androgens in pathological conditions (Bierich, 1963). Apart from the latter case, where masculinized baby girls result from adrenal hyperplasia, androgens in female fetuses were never observed to modify the pattern of differentiation. Modifications of normal sexual differentiation (Jost, 1955; Jost \& Picon, 1970) indicated that the timing of events is critical, as the period of sensitivity to androgens might not coincide with endogenous secretion of androgens, and female phenotypic differentiation would therefore not be impaired. Development during the critical phase is usually irreversible (Jost \& Picon, 1970). It is possible that other steroids might mask androgen receptors during the critical phase, or that androgen levels in female fetuses are simply lower than the threshold for masculinization (Wilson et al., 1980).

Gondos \& Hobel (1973) found that interstitial cells appear later in female human fetuses than in males, while the fetal testes of male rabbits secreted testosterone before the fetal ovary secreted hormones (Wilson et al., 1980). Therefore, masculinization of female spotted hyaena fetuses probably results from androgens acting on the common anlage to establish the male facies in both genders.

As in other mammalian species, the source of androgens in the male spotted hyaena fetus is believed to be the fetal gonad, and a similar endogenous origin is proposed for androgens found in the female fetus. No evidence of adrenal hypertrophy or adrenal secretion of androgens could be found over the age range of hyaena fetuses examined in this study, and the androgen content of the fetal adrenal is likely to be the result of perfusion with blood containing androgens from another source. Maternal androgens entering the fetal circulation via the placenta, or placental production of androgens is not supported by our findings, indicating the fetal ovary as a feasible alternative.

We therefore suggest that masculinization of the genital tubercle of female spotted hyaena fetuses results, as in the male, from an episode of androgen secretion by the fetal gonad, but with the difference that the Wolffian ducts of the female fetus do not respond to circulating androgens, due to a lack of sensitivity during the initial phase of differentiation. Matthews' (1939) suggestion that androgens are the cause of masculinization is supported by our findings, but androgens in the female fetal circulation are of fetal origin, as Racey \& Skinner (1979) suggested.

We are grateful to the Board of Trustees, National Parks Board of South Africa, and their staff for their kind co-operation in this project and to Professor R. P. Millar, Department of Chemical Pathology, University of Cape Town for assay facilities. M.L. was the recipient of a C.S.I.R. study bursary and the Charles Astley Maberly Memorial Scholarship of the Transvaal Branch of the Wildlife Society of Southern Africa.

\section{References}

Bierich, J.R. (1963) The adrenogenital syndrome. In Intersexuality, pp. 345-386. Ed. C. Overzier. Academic Press, London.

Buhl, A.E., Pasztor, L.M. \& Resko, J.A. (1979) Sex steroids in guinea pig fetuses after sexual differentiation of the gonads. Biol. Reprod. 21, 905-908.

Ellinwood, W.E., Brenner, R.M., Hess, D.L. \& Resko, J.A. (1980) Testosterone synthesis in rhesus fetal testes: comparison between middle and late gestation. Biol. Reprod. 22, 955-963.

Ford, J.J., Christenson, R.K. \& Maurer, R.R. (1980) Serum testosterone concentrations in embryonic and fetal pigs during sexual differentiation. Biol. Reprod. $23,583-587$.
Frazer, J.F.D. \& Huggett, A. St. G. (1974) Species variation in the foetal growth rates of eutherian mammals. J. Zool., Lond. 174, 481-509.

Gondos, B. \& Hobel, C.J. (1973) Interstitial cells in the human fetal ovary. Endocrinology 93, 736-739.

Huggett, A. St. G. \& Widdas, W.F. (1951) The relationship between mammalian foetal weight and conception age. J. Physiol., Lond. 114, 306-317.

Jost, A. (1955) Modalities in the action of gonadal and gonad-stimulating hormones in the foetus. Mem. Soc. Endocr. 4, 237-247.

Jost, A. \& Picon, L. (1970) Hormonal control of fetal development and metabolism. Adv. Metab. Dis. 4, 123-184. 
Lipsett, M.B. \& Tullner, W.W. (1965) Testosterone synthesis by the fetal rabbit gonad. Endocrinology 77, 273-277.

Matthews, L.H. (1939) Reproduction in the spotted hyaena Crocuta crocuta (Erxleben). Phil. Trans. $R$. Soc. (B) 230, 1-78.

Millar, R.P. \& Kewley, C. (1976) Production of a specific antiserum for testosterone. S. Afr. med.J. 50, 1021-1022.

Neaves, W.B., Griffin, J.E. \& Wilson, J.D. (1980) Sexual dimorphism of the phallus in spotted hyaena (Crocuta crocuta). J. Reprod. Fert. 59, 509-513.

Neumann, F., Elger, W., Steinbeck, H. \& Gräf, K.J. (1975) The role of androgens in sexual differentiation of mammals. In Intersexuality in the Animal Kingdom, pp. 407-421. Ed. R. Reinboth. Springer Verlag, Berlin.

Pointis, G., Latreille, M.T. \& Cedard, L. (1980) Gonado-pituitary relationships in the fetal mouse at various times during sexual differentiation. J. Endocr. 86, 483-488.
Racey, P.A. \& Skinner, J.D. (1979) Endocrine aspects of sexual mimicry in spotted hyaenas Crocuta crocuta. J. Zool., Lond. 187, 315-326.

Raeside, J.I. \& Middleton, A.T. (1979) Development of testosterone secretion in the fetal pig testis. Biol. Reprod. 21, 985-989.

Resko, J.A. (1970) Androgen secretion by the fetal and neonatal rhesus monkey. Endocrinology 87, 680687.

Schneider, K.M. (1926) Über Hyänenzucht, Pelztierzucht 2, 1-4.

Veyssiere, G., Berger, M., Jean-Faucher, C., De Turckheim, M. \& Jean, C. (1976) Levels of testosterone in the plasma, gonads and adrenals during fetal development of the rabbit. Endocrinology 99, 12631268.

Wilson, J.D., Griffin, J.E. \& George, F.W. (1980) Sexual differentiation: early hormone synthesis and action. Biol. Reprod. 22, 9-17.

Received 15 September 1981 